\title{
FREUD, HIS ILLNESS, AND OURSELVES
}

\author{
André Haynal
}

The history of Freud's illness shows that he tried to avoid confrontation with it, and to treat it as unimportant. In his personal letters, the ill body remains outside-as another person, "Konrad," not he himself-and it is not taken into account. Particularly in Freud's correspondence with Ferenczi, we realize to what extent certain phenomena, especially depressive ones, he considered somatic, with a tendency to dismiss them, and this despite important occasional insights, such as about the role played by hate in psychosomatic illnesses. In the post-Freudian development, these topics have been more and more integrated in the dialogue, in the discourse between the analyst and the analysand.

KEY WORDS: Freud's physical illness; history of psychoanalysis; psychosomatic medicine; psychoanalytic dialogue.

DOI:10.1057/ajp.2008.2

I.

Since mid-February 1923, Freud could no longer fail to realize that he had a tumor in his mouth. As a matter-of-fact, six years earlier, in 1917, he had already noticed a similar, painful swelling on his palate. Ironically, that tumor disappeared after a patient had offered him a beautiful box of Cuban cigars, an enchanting oasis of blue smoke in the midst of the upheaval of WWI that shook the whole world. At that time, Freud did not attach much importance to the pain (cf. Schur, 1972, p. 310). Without doubt, he feared that he might be forbidden to smoke. In 1923, however, the tumor had grown too large for him to ignore. At that time, as in the case of his previous cardiac condition, Freud still had no physician whom he would have consulted regularly, although he was surrounded by physicians.

André Haynal, M.D., is past president of the Swiss Psychoanalytical Society and former Vice President of the European Psycho-Analytical Federation, Professor of Psychiatry (Emeritus), University of Geneva, Switzerland, Training and Supervising Analyst, Swiss Psychoanalytic Society.

Address correspondence to André Haynal, M.D., 5 bd Philosophes, CH-1205 Geneva, Switzerland; e-mail: andre.haynal@freesurf.ch

Paper presented at the Clinical Sándor Ferenczi Conference, August 2-6, 2006, BadenBaden, Germany. 
He had suspected the illness before that fateful year of 1923. It appeared like a premonition that in May 1921 he wrote that strange letter to Ferenczi, in which, on the occasion of his 65th birthday, he wrote that "seven organs are vying with one another for the honor of being allowed to make an end to my life" (Freud and Ferenczi, 2000, p. 56).

Anyhow, at the end of the second week of April 1923, when The Ego and the Id (Freud, 1923b) was published, Freud consulted the dermatologist Max Steiner. Steiner examined him and concluded that it was a malignant tumor, an epithelioma. He advised an excision, but deceived Freud in telling him that it was a leukoplakia (Schur, 1972, p. 350). Schur comments in his book that leukoplakia, a benign tumor, a pre-cancerous lesion of the oral mucosa, is associated with chronic tobacco abuse, and adds: "Steiner ... told Freud to give up smoking, a medically sound but untimely piece of advice. Judging from my later experience, this advice was much more threatening and unacceptable to Freud than surgery" (ibid.).

In the same week, Felix Deutsch payed a visit to Freud for private reasons. The Professor "took him aside as he was about to leave and asked Deutsch to look at his mouth, remarking: 'Be prepared to see something you won't like'" (ibid.). He was right. Deutsch examined him in the twilight of the window, and "at the very first glance" realized that he "was dealing with an advanced cancer. To play for time [to think], I made a second examination and decided to call it 'a bad case of leukoplakia,' due to tobacco abuse, which would make a biopsy and excision of the tumor necessary. Freud promised to follow the recommendation and told me that he had had this lesion for a long time already, and that it recently became exacerbated" (Deutsch, 1956, p. 297).

Felix Deutsch, the husband of Helene Deutsch, was a general practitioner, who was analyzed by Siegfried Bernfeld. He had organized the first clinic for "organic neuroses" in 1919, where a course on what later became known as psychosomatics was given. He was light years removed from oncology. How could he diagnose with certainty a malignant tumor in looking into the mouth in the dim light coming from the window? From the beginning, things did not match up.

According to Jones, Deutsch was "discomposed to hear Freud ask him for help to 'disappear from the world with decency' if he was doomed to die in suffering. Then Freud spoke of his old mother, who would find the news of his death very hard to bear. ... So Deutsch contented himself by saying there was a simple leukoplakia which it was advisable to remove" (Jones, 1957, p. 90).

Soon afterwards, a doctor, a zhinologist was chosen. We can ask ourselves: Why did he choose Markus Hajek? Why not have recourse to a 
renowned specialist-Marais Pichler, for example? The answer is not easy. According to Anna Freud, it was Freud himself who made the decision (Gay, 1987, p. 419).

Freud presented himself at the clinic, at the time agreed upon, without telling anybody at home. He was operated on while sitting on a chair (Schavelzon, 1983, p. 57). In his book, Schavelzon shows a photograph of this operating theater: a dark and plain room, which is rather reminiscent of a waiting room in some city healthcare center. To mention just one fact: Deutsch accompanied the patient, but did not remain with him during the operation.

The operation was performed with local anesthetics, and consisted in the ectomy of the anterior right palate, an incision that went as far as the right dental border. After two hours, the operation was interrupted due to a strong hemorrhage, and the wound was not closed with organic tissue (ibid.).

The operation was terminated with the stopping of the strong hemorrhage, and a message sent to the family: "Bring clean clothes." Martha and Anna hurried to the hospital, where they found Freud sitting on a kitchen chair, with blood all over his clothes. There was no free room or even a bed in the clinic, and so a camp bed was rigged up in a room already occupied by a patient, whom Anna Freud later described as "a retarded dwarf" (Gay, 1987, p. 419). As the story goes, this retarded dwarf saved the life of the Professor. Martha and Anna had to leave the hospital, as no visitors were allowed during mealtimes. Upon their departure, they were reassured that the patient would be all right. When they returned, however, they learned that he had had a new attack of profuse bleeding. The bell had been out of order, and Freud found himself helpless. Fortunately, the dwarf rushed for help, and after some difficulty the bleeding was stopped (Schavelzon, 1983, p. 58).

After this terrible episode, Anna refused to leave her father alone. "The nurses," she wrote, "did not have a good conscience about the failure of the bell, [and] were very kind. They gave me black coffee and a chair and my father, the dwarf and I spent the night together" (Gay, 1987, p. 420). In the morning, there was a new hemorrhage. There was no house surgeon present at the hospital (Jones, 1957, p. 91), and Anna dressed the wound. Freud was weakened by the loss of blood, half-drugged from the medicines, and was in great pain. The next morning, Hajek, with the morbid thick skin of physicians, demonstrated the case to a crowd of students. The patient's state did not permit a transferral to a more appropriate clinic, although the highly renowned Löw Sanatorium was only a block away; it was in this institute that future operations were performed. The next day, Freud left this sombre clinic to rejoin his family. Thus ended the first of the 33 operations Freud underwent before the fatal end in 1939. 
In sum, the intervention was a disaster. First inconsistency: Was an operation of more than two hours, including the ablation of half the palate, really superficial? According to Jones, the biopsy revealed that the tumor was cancerous. Although the tissue was analyzed, we do not know by whom the biopsy was made, and a report never surfaced. On the other hand, Hajek did not take the usual precautions to avoid the retracting of the tissue scarring over. The result was a considerable contraction, which caused great pain after the operation. This was an unforgivable error. From then on, the most painful problem, and the one most difficult to address, was this tissue "contraction," the main reason why none of the future prostheses was satisfactory. The heavy apparatus, which covered the concavity of the palate, became a veritable instrument of torture, a symbol of his suffering.

Hajek did not write down a medical report, and prescribed X-ray treatment, followed by treatments with radium capsules. Freud did not react well to the treatment: generalized pains, headaches, vomiting, and fatigue were the consequences of the radiotherapy. Max Schur gave his medical opinion, corresponding to that of Schavelzon: "first, radiotherapy for this type of malignancy is usually unsuccessful. This was later stated by the experts Professors Rigaud and Lacassagne, directors of the Institut Curie in Paris. Second, radium treatment, outside of Paris and especially in Vienna, was carried out somewhat haphazardly. The radiation Freud received only caused tissue damage and violent pain" (Schur, 1972, p. 357). Schavelzon writes: "We have no technical references for the treatment with radiotherapy, and, as far as the radium is concerned, the dosage was disproportionate" (1983, p. 61). Schur goes even as far as saying that "until 1936 there were no pathological signs of a malignant cancer" (1949, p. 74).

As far as the history of Freud's "illness" is concerned, recent studies have revealed that the story is not as simple and straightforward as it is recounted in the traditional literature, and that Freud probably did not yet suffer from cancer when the first surgical intervention took place. For instance, there is no trace of any trustworthy cytological examination in the early stages. It has even been suggested that it was precisely those various interventions and re-operations that played a part in rendering the leukoplakia malignant. Let us remind ourselves that it was only as late as in 1936 that the diagnosis of Freud's cancer could be established on scientific grounds (Schavelzon, in Rodrigué II, 1996, pp. 287ff.).

After the last of the 33 operations, when Freud was informed about his situation, he wrote to Eitingon on March 5, 1939: "Now we know, more or less, where we are standing. A biopsy showed that it really is an attempt of the carcinoma to again take my place" (Freud and Eitingon, 2004, p. 920; italics added). 
II.

How did Freud live with his illness, what did he think about it, and what can all this teach us psychoanalysts today?

What made Freud write in 1922, shortly before that fateful year when his tumor was discovered, "that the analytic treatment of gross organic diseases is not unpromising, since a mental factor not infrequently contributes to the origin and continuance of such illnesses" (1923a, p. 250)? It is true that he also wrote to Viktor von Weizsäcker: "For pedagogical reasons, I had to keep analysts from making such examinations. ... [T] hey had to learn to confine themselves to psychological ways of thinking. We may be grateful to the internist to have widened the scope of our insights. ... [Our] attention has been called to the psychogenetic factors in organic illnesses ... [and also to the fact that] a neurosis can often be followed and substituted by an illness" - all of which would give "the impression of a provisional state" (October 16, 1932; in Weizsäcker, 1954, pp. 182-185).

Although many terms in psychoanalytic theory point to the importance of somatic roots of psychic life-such as the concepts of drives or instincts, the dimension of sexuality, which is also based on the biology of the human being before becoming phantasy, or the ego, which is initially also conceived as a body ego-this approach to and treatment of the bodily dimension seems to have been fragmentary and fraught with difficulties. Is this so because of a methodological question, as the just-quoted passage seems to indicate? Or because of the necessity to concentrate on what is important, namely, the psychical? All this despite the fact that the scientific group around Freud, the "Wednesday Society," or later the Viennese Psychoanalytical Society, was to a large part composed of general practitioners and of so-called Badeärzte—balneologists and physical therapists. Freud himself, however, was not particularly well versed in physical medicine (with the exception of neurology, especially pediatric neurology).

In addition, Freud's personal texts are full of his preoccupation with the state of his health. In his early letters to Abraham, for example, that is to say toward someone whom he hardly knows yet, and with whom he is not yet on intimate terms, he is ready to make frequent allusions to various health problems. On February 16, 1908, for instance, he writes of "the recovery, more or less, of the domestic patients" (Freud and Abraham, 2002, p. 27; italics added); on March 1, he remarks that his "daughter left ... to convalesce" (ibid., p. 30); on July 11, he feels "in great need of the holiday" (ibid., p. 49); on April 27, 1908, he suffers from a "conjunctivitis" (ibid., p. 88); on May 23, he is "too tired to work" (ibid., p. 92), etc. The same can be said of his letters to other correspondents (e.g., to Lou 
Andreas-Salomé). Even before their famous meeting in Munich in 1910, he writes to Jung on December 22, 1910: “Don't be dismayed if you do not find me in the best of health" (Freud and Jung, 1974, p. 382), and again, shortly afterwards: "strange headaches ... lapses of memory" (ibid., p. 393)— later attributed to gas escaping from the gas lamp in his study-which Freud initially "diagnosed ... as arteriosclerosis, to which I resigned myself" (ibid., p. 394), another factor that moved Freud to nominate Jung to be elected the life-long president of the International Psychoanalytic Association (IPA).

In any case, all this seems to indicate a strange avoidant behavior. Let me explain by making a small detour via Switzerland, and by introducing the author of a book that plays a central role in this. Carl Spitteler (pseudonym of Carl Felix Tandem), born in 1845 in Liesthal, the capital of the Swiss demicanton "Basel-Land," deceased in 1925 in Lucerne, was awarded the Nobel Prize in 1919, inter alia for his neutral, "Swiss" stance during the First World War. This political attitude alone may have been responsible for the sympathies he gained in Freudian circles, but it was above all his book Imago, which appeared in 1906, that was greeted with enthusiasm. It was Jung (1911-1912) who introduced this term ("imago") into the psychoanalytic nomenclature. This term was, however, also adopted, and used in the title of the journal founded in 1911 by Hanns Sachs and Otto Rank (to this day, an American Imago is still published). The novel's main character, Victor, "was accustomed ... to calling his body Konrad" (p. 21). This metaphor was borrowed by Freud (who often connected it to armerpoor-Konrad), and became standard jargon in the letters exchanged by the psychoanalytic pioneers. They did not address their body as such, but talked as if about the "other" —Konrad, that is (cf. Freud's letters to Ferenczi (Freud and Ferenczi, 1993, p. 408) and Abraham (Freud and Abraham, 2002, p. 552)). In German culture, by the way, this name also alludes to the secret associations of poor peasants, who called themselves "Armer Konrad" during the Peasant's Wars in Germany (1514), after the pejorative name given to them by nobility. Konrad is thus sort of a poor guy, a strange double, a doppelgänger, who is able to make himself felt from time to time, in a perturbing way, unexpectedly and mysteriously, without his appearances being foreseen or understood.

One may be inclined to think that the evocation of methodological problems and the habit of talking about "Konrad" served to avoid a direct confrontation with somatic problems. As we have seen, however, and as we will still see more fully, the preoccupation with the ill body did not stop. 
Freud and Ferenczi often took the waters, in Karlsbad, among other places, one of those spas with their strange, nostalgic atmosphere, which stimulated reminiscences, and concentrated their visitors' attention on their body, their needs, and their wishes (this atmosphere was later captured in a famous film about Marienbad, another one of those spas). During one of these stays, Freud made the following comment on August 5, 1913: "I am unmistakably in a toxic condition similar to the one you saw me in last year, and even more similar to the one I had at the beginning of the first Karlsbad cure. Moody, irritable, tired $[\mathrm{sic}]$, but this time no weakness of the heart. Always ruminating over the same dark thoughts [sic], taking little things hard, aversion to food, but after filling my stomach, I regularly brighten up" (Freud and Ferenczi, 1993, pp. 504-505). Here the irritability, the dark thoughts, and the fatigue are not considered as belonging to the psychic domain, but are viewed as somatic troubles, to be cured in the spa, and not by psychic exploration.

Not so Ferenczi, however, who comments on October 3 of the same year with regard to Freud's recurring gastric troubles: "[L]et us hope the stomach ailment will turn out to be a transitory symptom. We should actually-according to the experiences of the last few years-already be better acquainted with the conditions that at times have an unfavourable influence on your health ... For my part, I maintain that Karlsbad and the Karlsbad cure are disadvantageous to you. The toxic effect has always set in promptly; we have never seen any favourable effects" (ibid., p. 510). Freud answers on October 12: "I am certainly ready to give up the drinking cures, to which I owe something, completely normal intestinal functioning, which has been undisturbed for three months now. I just took a first step toward looking after myself; I gave up the hour between 8 and 9 in the morning, i.e., I dismissed the designated patient without replacing him" (ibid., p. 513).

\section{III.}

Having become witnesses of the degree of intimacy that existed between Freud and Ferenczi, we may now be able to better understand that Ferenczi could suggest to the Master, on February 26, 1926, to take Freud into analysis because of his cardiac and gastric troubles: "What do you say about the strange coincidence that, just now, when you are concerned about heart ailments, from the many cases that were being presented by us, I happened to cite the theme of coronary disturbances. What was said there is plainly already an answer to what you have heard. I am firmly convinced that-even if nicotine plays a part in the matter-something psychic can be decisive in the so-called myocardites and stenocardias" 
(Freud and Ferenczi, 2000, p. 250). Let us note that Ferenczi, with his remarkable intuition, writes of "so-called" myocardites and stenocardias, something that was proven by the following years, as Freud's heart never gave out during the whole 83 years of his life. Ferenczi goes on writing: "As vehemently as I pleaded in favour of intervention in the solution of your jaw malady, I believe just as decidedly that the heart can and should be not only medicinally but also psychically supported. Perhaps this is the occasion on which I can say to you that I find it actually tragic that you, who endowed the world with psychoanalysis, find it so difficult to beindeed, are not at all-in a position to entrust yourself to anyone. ${ }^{1}$ — If your heart ailments continue, and if the medications and diet don't help, then I will come to you for a few months and place myself at your disposal as an analyst-naturally: if you don't throw me out" (ibid.; italics added).

Although quite a few of his disciples (including Rank) tried, during the course of their relationship with Freud, to contribute to a psychoanalytic understanding of his illness, only Ferenczi and Groddeck (cf. Freud and Groddeck, 1970) offered in all seriousness and resoluteness to take Freud himself into analysis. Did Freud think-given the developmental state of his theory at the time-that psychoanalysis was not yet ready to treat somatic manifestations and physical illnesses, whether or not they were of "organic" origin? Even if it was perhaps out of the question for Freud to turn to whomever it was for analysis, would it have been possible that Ferenczi or Groddeck had been able to really help him? Could Freud have risked to show himself vulnerable (notabene, in a state of dependency) at the age of 70 or even older? Perhaps Ferenczi was right in thinking that the Master was in no position to entrust himself to anybody. We can easily imagine the difficulty of entering into a state of submission and dependency with someone Freud might have seen as "inferior," in analytic understanding, to him, the discoverer of psychoanalysis. Perhaps it was not the heart that was the problem, but what he could not, and did not want to see.

In any case, he eventually chose the so-called Steinach operation, an allegedly endocrinal-organic intervention, to reinforce his (hormonal) resistance against the forces of the illness-instead of a psychoanalysis that could have also been considered in this perspective.

Tired of therapy, "saturated" and "fed up" by analysis as a therapy, he writes to Ferenczi on January 11, 1930: "Very possible that you are doing analysis better with both, or with all, your patients than I am (Sie bei beiden oder allen Patienten die Analyse besser machen als ich), but I also don't have anything against that. I am saturated with analysis as therapy, 'fed up,' und who, then, should[...] do it better than you? (wer sollte es besser machen, wenn nicht sie)" (Freud and Ferenczi, 2000, p. 380; italics added). 
If we admit that Freud was discouraged with regard to the curative power of psychoanalysis the way he practiced it, is it thinkable that it was health troubles that led him, at least partly, in his later works of the years around 1936-1939-a few years after the death of Ferenczi, and after having worked through his mourning - to again take up some of the latter's ideas, in particular the topics of splitting, of introjection, of the role of the mother, thus indirectly touching also on the "dark continent" (Freud, 1926, p. 212)?

In any case, returning to Ferenczi's offer to analyze him, Freud thanks him warmly for this "touching suggestion," adding that " $\mathrm{t}]$ here may indeed by a psychic root" (February 27, 1926; Freud and Ferenczi, 2000, p. 252). Which "psychic root"? Is this about that state of anxiety he describes to Eitingon on March 22, 1924: "I am constantly tortured by one thing or another" (Freud and Eitingon, 2004, p. 344)? Or did he anticipate further developments, telling Thornton Wilder, the American writer, in 1938, "that it might some day be shown that cancer is allied to the presence of hate in the subconscious'" (in Freud, 1992, pp. 297-298)? And if hate it is, what is it about? Could this have to do with the "dark continent" and the difficulties he had with his mother, difficulties his biographers begin to grasp? The mother had lost a son a year before the birth of Sigmund, and, a year later, gave birth to him, and was thus in a state of mourning at the beginning of his life-and this in spite of all his idealization of her; after all, we know what lies behind such idealizations.

Let us remind ourselves of the fact that he did not care to go to the funeral of his mother in 1930, but instead preferred to send his daughter Anna-always the poor Anna-to represent him. Ferenczi thought that Freud had "sacrificed" the interests of women, and that "he wants to ignore the traumatic moment of his own castration in childhood" (Ferenczi, 1985, p. 188). Without any doubt, there existed a tension between Freud and his mother.

Taking this as a point of departure, it is perhaps possible that he did not know how to take good care of himself, just as his mother could not take good care of him, and that he lacked an image of a sufficient, comfortable, and efficient enough mother, to whom he could turn and confide in. A link is conceivable between Freud's denial of the body and his work on negation, published in 1925. What does he want to verneinen, to negate? Could this not be the "dark continent," of which he writes in the following year? (Freud, 1926, p. 212).

Is there a connection between the attempts to eliminate, or trivialize, the somatic dimension, and Freud's core drama, of which we find traces in his personal writings, and particularly in his correspondence with Ferenczi? His problem with his mother seems to have given rise to a not 
very kind attitude towards himself, a sort of masochism—a problem he also tried to grasp in his speculations about the death instinct.

He neglects his own health, while complaining constantly and without reserve in a depressed mood, and indulging in his passion for tobacco, a particularly destructive passion in his state. On June 1, 1931, he writes to Eitingon that "in view of my age and the degree of uncomfortableness I have to suffer each day, abstinence [from tobacco] ... does not seem justified to me" (Freud and Eitingon, 2004, p. 739). Did Freud, during his whole life, follow a masochistic tendency in his series of breaks with the better part of his disciples and friends? Even Abraham could perhaps have had the same fate if he had lived long enough, as we might suspect when reading their correspondence. Already early on Freud complained about his "splendid isolation" (Freud, 1914, p. 22). He also confessed not to have profited from the sexual revolution he helped to set in motion (Hale, 1971, p. 376). Was it also because of his masochism that Freud refused, for a long time, to emigrate, at the risk of his life?

In intense identification with the masochism of his daughter, he used Anna's case to write his own article entitled "A child is being beaten" (Freud, 1919). Young-Bruehl (1988, pp. 103-104) writes that Freud's article is partly based on Anna and her analysis with him (i.e.: of the six patients discussed, one is probably Anna). Anna Freud in her turn took Freud's article as the starting point for her later work on beating phantasies and daydreams $(1922 a, b)$. Here, too, the patient on whom this text is based seems to be Anna herself.

Let us note that in his remarks to Ferenczi on Anna's Oedipus, he apparently does not realize that he might himself be partly at the source of his daughter's masochism. To Lou Andreas-Salomé, he writes (July 3, 1922): "In her relations to men, she is inhibited because of me. Up until now, she has had much misfortune in her friendships with women. ... Sometimes I desperately wish her to have a good man, sometimes I am shying away from the loss." And when he takes her into analysis for a second time: "I have undertaken a seventh analysis with quite special feelings: my Anna, who is so unreasonable as to cling to an old father" (May 13, 1924) (Falzeder, 2003, p. 89).

\section{IV.}

Some may feel discomfited that I am not giving an image of Freud the God, but of Freud the human being, which, however, in my opinion does not at all diminish his genius or the value and impact of his ideas, even if his insights also had their limits. It seems, by the way, that Einstein was 
wrong with his last great theory-but he and Freud remain no less beacons of humanity.

Personally I am more interested in Freud's personality, his position, the biographical and historical places he takes as a starting point for his discourse, and the development of his theory, than by an exegesis of his texts that is robbed of all its historical context. There is no doubt that personal experiences feed and enrich psychoanalytic thinking. It can be enlightening to understand the links between the lives of great psychoanalytic thinkers and the elaborations, even if sometimes hypothetical, of their theories. Writing the history of psychoanalysis is not a foolish enterprise. The history of ideas can become crucial: historia docet, history teaches us, and we can draw conclusions from it for ourselves.

We could go on with a more detached Freud, a more philosophical one, as it were, discovering other biases to deepen our understanding of the problem of the "ill." I cannot enter here into a detailed chronological study of this problem, but it is for instance tempting to listen to what he writes in the middle of the First World War, in his little gem of a piece entitled Vergänglichkeit, "On transience" (Freud, 1916). During one of his famous walks "through a smiling countryside" (p. 305), in the company of a young poet, probably Rilke, and "a taciturn friend," he talked about mourning and the liberation it can bring about: "our capacity for love (our libido) is once more liberated" (p. 306). We sense an effort to bring about positive transformations, a better solution, as he says on the occasion of another walk in September 1917, accompanied by Anna. She expressed her wish that she could stay here forever, that everything could stay the same as it was at that moment. Freud answered that one experiences pleasure in the moment because it is transitory. The idea struck Anna as strange and without meaning (Unwerth, 2005, pp. 192-193). Later, on May 12, 1923, she wrote to Lou Andreas-Salomé, with reference to that scene, that something very secretive and true could be hidden behind those words. In reading Beyond the Pleasure Principle (Freud, 1920) with its Nietzschean undercurrents, she thought that this eternity and peace, which arose nostalgia in her, were nothing but death itself. It is the same in the ninth of Rilke's Duino Elegies, in which transience leads to liberation.

And what about ourselves? To return to the context of "Freud, his illness, and ourselves" in view of what has been said, we can understand that Freud eventually did not make a lasting contribution to psychosomatic medicine; this work was left to his successors. Freud's creativity was in constant progression, fuelled by new ideas, and so his theory is composed of multiple strata. His intuitions - as of the role played by hate in cancerwere not further elaborated by himself, but have resurfaced later in other important contributions. 
What I find even more important is that we remind ourselves of the fact that Freud conceptualized psychoanalysis in one self-analysis, in the writing of his principal work, The Interpretation of Dreams (1900). This was not a "talking cure," to borrow Anna O.'s expression, but a "writing cure." This also contributes to the fact that the defense mechanisms studied by Freud, such as repression or censorship, are linked to the act of writing, in contrast to projection, introjection, and splitting, which appear in the later development of psychoanalytic thinking, conceived during the maternal listening and the participation in the "inside" of the other.

What Freud lacks is dialogue on this deeply intimate subject. Numerous times he writes to his followers (Rank, among others) that it is not so important to be analyzed by someone else; a study of one's own dreams would suffice. Perhaps Freud's illness was eventually his isolation, having no partner to think and reflect with. We have since learned that it is in the relational experience, in the exchange of a deep dialogue, open to accepting the other's thinking that we find the cornerstone of a return to the speech, the "talking cure" - a form of human solidarity that perhaps sometime even opens up for us the secrets of the soma, too.

It is through this speech that "Konrad" can be heard, become audible, and become part of ourselves, by putting these ills into words.

As a matter-of-fact, from its beginning, psychoanalysis is a theory of the "ill" ness. According to Freud's dictum, hysterics suffer from reminiscences, from the memory of traumatic scenes, and we can help them in overcoming that illness by talking in a kind of debriefing, as it would be called today. It is in this discourse that hopes of transformations and changes can arise. As has been shown by some authors, Freud's thoughts about the problem of the "ill" 2 can impress us by their pertinence. They do not, however, seem to have helped him much.

\section{NOTES}

1. And above all not to someone considered a pupil or a disciple.

2. For other perspectives on the topic of Freud and illness, see Romm (1983) and Kollbrunner (2001).

\section{REFERENCES}

Andreas-Salomé, L. \& Freud, A. (2001). In D.A. Rothe \& I. Weber (Eds.), “... als käm ich heim zu Vater und Schwester." Briefwechsel 1919-1937. Göttingen: Wallstein.

Deutsch, F. (1956). Reflections on Freud's one hundredth birthday. Psychosomatic Medicine, 18, 279-283.

Falzeder, E. (2003). Die Anfänge der Kinderpsychoanalyse. Studien zur Kinderpsychoanalyse, 19, 84-104. 
Ferenczi, S. (1985[1932]). In J. Dupont (Ed.), The clinical diary of Sándor Ferenczi. Cambridge, MA: Harvard University Press, 1988.

Freud, A. (1922a). Schlagephantasie und Tagtraum. Imago, 8, 317-332.

Freud, A. (1922b). The relation of beating phantasies to a day dream. International Journal of Psychoanalysis, 4(1923), 89-102.

Freud, S. (1900). The interpretation of dreams. Standard Edition (Vols. 4, 5). London: Hogarth Press.

Freud, S. (1914). On the history of the psycho-analytic movement. Standard Edition (Vol. 14, pp. 7-66). London: Hogarth Press.

Freud, S. (1916). On transience. Standard Edition (Vol. 14, pp. 303-308). London: Hogarth Press.

Freud, S. (1919). A child is being beaten. Standard Edition (Vol. 17, pp. 179-204). London: Hogarth Press.

Freud, S. (1920). Beyond the pleasure principle. Standard Edition (Vol. 18, pp. 7-64). London: Hogarth Press.

Freud, S. (1923a). Psychoanalysis, the libido theory. Standard Edition (Vol. 18, pp. 235-259). London: Hogarth Press.

Freud, S. (1923b). The ego and the id. Standard Edition (Vol. 19, pp. 12-59). London: Hogarth Press.

Freud, S. (1925). Negation. Standard Edition (Vol. 19, pp. 235-242). London: Hogarth Press.

Freud, S. (1926). The question of lay analysis. Standard Edition (Vol. 20, pp. 183250). London: Hogarth Press.

Freud, S. (1992). In M. Molnar (Ed.), The diary of Sigmund Freud, 1929-1939. A record of the final decade. New York: Charles Scribner's Sons.

Freud, S. \& Abraham, K. (2002). In E. Falzeder (Ed.), The complete correspondence of Sigmund Freud and Karl Abraham. London: Karnac Books.

Freud, S. \& Eitingon, M. (2004). In M. Schröter (Ed.), Briefwechsel 1906-1939. Tübingen: edition diskord.

Freud, S. \& Ferenczi, S. (1993, 2000). In E. Falzeder \& E. Brabant (Eds.), The correspondence of Sigmund Freud and Sándor Ferenczi, 1908-1933 (Vols. 1 and 2), Cambridge, MA: The Belknap Press of Harvard University Press.

Freud, S. \& Groddeck, G. (1970). In M. Honegger (Ed.), Briefe über das Es. Frankfurt am Main: Fischer Taschenbuch Verlag. The meaning of illness: Selected psychoanalytic writings [of Georg Groddeck], including correspondence with Freud. London: Karnac, 1988.

Freud, S. \& Jung, C.G. (1974). In W. McGuire (Ed.), The Freud/Jung letters. The correspondence between Sigmund Freud and C. G. Jung. Cambridge, MA: Harvard University Press, 1988.

Gay, P. (1987). Freud, a life for our time. New York, NY: Anchor Books, 1989.

Hale Jr., N.G. (Ed.) (1971). James Jackson Putnam and psychoanalysis. Cambridge, MA: Harvard University Press.

Jones, E. (1957). The life and work of Sigmund Freud. Vol. 3: The last phase, 1919-1939. New York, NY: Basic Books.

Jung, C.G. (1911-1912). Wandlungen und Symbole der Libido. Jahrbuch für psychoanalytische und psychopathologische Forschungen, 3, 120-227, 4:162-464. Symbols of transformation. Collected Works 5.

Kollbrunner, J. (2001). Der kranke Freud. Stuttgart: Klett-Cotta.

Rodrigué, E. (1996). Sigmund Freud. El siglo del psicoanálisis. Buenos Aires: Editorial Sudamericana. Freud. Le siècle de la psychanalyse. 2 Vols. Paris: Désir Payot, 2000. 
Romm, S. (1983). The unwelcome intruder. Freud's struggle with cancer. New York, NY: Praeger.

Schavelzon, J. (1983). Freud, un paciente con cáncer. Buenos Aires: Paidós.

Schur, M. (1949). Necrology of Pichler. Bulletin American Association of Psychoanalysis, 5, 74.

Schur, M. (1972). Freud: Living and dying. New York, NY: International Universities Press.

Spitteler, C. (1906). Imago. Frankfurt am Main: Suhrkamp Verlag (1979).

Unwerth, M. (2005). Freud's requiem. Mourning, memory, and the invisible history of a summer walk. New York, NY: Riverhead Books.

Weizsäcker, V.v (1954). Natur und Geist. Erinnerungen eines Arztes. Göttingen: Vandenhoeck \& Ruprecht.

Young-Bruehl, E. (1988). Anna Freud, a biography. New York: Summit Books. 